\title{
Youth Health Risk Behavior Surveillance during Medical Education Period

\author{
Ucar $\mathrm{O}^{1}$, Tekgul N${ }^{2 *}$
}

${ }^{1}$ Izmir University of Health Sciences, Tepecik Training and Research Hospital, Clinic of Family Medicine, Izmir, Turkey

${ }^{2}$ Nurdan Tekgul MD, Izmir University of Health Sciences, Tepecik Training and Research Hospital, Clinic of Family Medicine, Izmir, Turkey

\author{
DOI: $10.36347 /$ sasjm.2020.v06i02.005 \\ | Received: 03.02.2020 | Accepted: 19.02.2020 | Published: 22.02.2020 \\ *Corresponding author: Nurdan Tekgul
}

Abstract

Original Research Article

Our objective is to find youth health risk behavior surveillance during medical education period. The investigation was performed between January-December 2013, in regular public and medical schools in Izmir. A total of 1040 students (male: 484, female: 556) aged 17-20 years (mean \pm SD: $18.9 \pm 1.9$ years) were included on a voluntary basis in this cross-sectional questionnaire survey. The questionnaire form included items on subject demographics (age, gender), and questions designed in context of the Centers for Disease Control and Prevention's "Youth Risk Behavior Surveillance, 1999". The questionnaire revealed significantly increased risk behavior ratesi during medical education period in the study cohort: traveling in the vehicle not wearing the belt in $499(48 \%)$, smoking regularly in 137 (13.2\%), drunk driving in $48(4.6 \%)$ suicidal ideation in $109(10.5 \%)$, suicide attempts in 30 (2.9\%), uncontroled sexual experience in $165(15.9 \%)$, owerweight in 235 (22.6\%). and using computer regularly all day ratio in (65\%). We concluded that spesific educational programmes must be taken covered in family life, pre-school and school period for youth health risk behavior.

Keywords: Adolescent period, medical students, behavior, risk.

Copyright @ 2020: This is an open-access article distributed under the terms of the Creative Commons Attribution license which permits unrestricted use, distribution, and reproduction in any medium for non-commercial use (NonCommercial, or CC-BY-NC) provided the original author and source are credited.

\section{INTRODUCTION}

Adolescence is a period that physical, sexual and psychological changes take place. It is between the ages 10-24 years (early adolescent period;10-14 years, middle adolescent period;15-17 years), late adolescent period (18-24)) constitude $1 / 7$ th of lifespan. The ages between 10-19 years account for $1 / 5$ th of the world population. 4/5th of the youth live in the developing countries [1,2]. During this period, many adaptation problems, independence and responsibility improve [3]. Adolescence, unfortunately, is also a period fraught with many threats to the health and well-being of adolescents in which many suffer substantial impairment and disability [4].

Priority health-risk behaviors during adolescence accompanies adolescent's normal physical, sexual and physo-social development. Adolescents have immature cognitive features and a giant curiosity which carry them easily to take risky behaviors. Drug use and sexual activity are the mostly performed risky behaviors during middle and late adolescent period. Priority health-risk behaviors, which are behaviors that contribute to the leading causes of morbidity and mortality among youth and adults, often are established during childhood and adolescence, extend into adulthood, and are preventable [5].

During adolescence, the leading causes of fatalities which are accidents and suicides, closely related to risky behaviors [6]. In the same way the first two ranks in adulthood mortality which are cardiovascular diseases and cancers, are closely related to the risky attitudes and behaviors such as smoking, alcohol or other substance abuse, physical inactivity, unhealthy diet [7].

Leading causes of mortality and morbidity among all age groups in the United States are related to the following six categories of health behavior: behaviors that contribute to unintentional and intentional injuries; tobacco use; alcohol and other drug use; sexual behaviors that contribute to unintended pregnancy and sexually transmitted diseases (STDs), including human immunodeficiency virus (HIV) infection; unhealthy dietary behaviors and physical inactivity [8]. As other age groups, adolescents while there may be acute and chronic medical problems, at this stage, important part of the diseases, death and 
disability are related risky behaviors and environmental related risks [9].

To monitor priority health risk behaviors among youth and young adults, CDC developed the Youth Risk Behavior Surveillance System (YRBSS) [10]. The YRBSS includes national, state, territorial, and local school-based surveys of high school students. National surveys were conducted in 1990, 1991, 1993, 1995, 1997, and 1999. In Turkey we need studies to reveal the size of the risky behavior in during medical education period). Two previous study provide preliminary data in high school students in the provinces of the West part of Turkey $[11,12]$.

In this cross-sectional questionnaire study we investigated to define youth health risk behaviors in medical students.

\section{MATERIALS AND METHODS}

The investigation was performed between January-December 2013. The study cohort was consisted of all regular public and medical schools with students between 17-20 (mean age 18.9) years old. Totaly 1040 students, 556 female $(53.5 \%), 484$ men $(46.5 \%)$ were included from 3 medical university; Ege University: 541 ( 52\%), Dokuz Eylul University : 358 $(34.4 \%)$ and Izmir Katip Celebi University: 141 $(13.6 \%)$. There was $411(39.5 \%)$ students in 1st class, $334(32.1 \%)$ students in 2nd class students and 295 (28.4\%) students in 3rd class. $24.3 \%$ were living at home, where $23.5 \%$ lived together with their friends and $28.8 \%$ lived in student residence.

Study was designed to protect students' privacy by allowing for anonymous and voluntary participation. Data was collected using a questionnaire which consisted of contains 56 multiple choice questions. The questionnaire form included 9 questions on subject demographics (age, gender, graduated highschool, home city, parent's marrital status, place where they lived). Other questions were designed in the context of the Centers for Disease Control and Prevention's " Youth Risk Behavior Surveillance, 1999". After explanation of the questionary, verbal approval was asked. Statistical analyses was conducted on weighted data using SPSS 18. Then the results were assessed statistically by chi-square test. Differences between prevalence estimates was considered statistically significant if the $\mathrm{p}$ value is $<0.05$ for main effects.

Written informed consent was obtained from each subject following a detailed explanation of the objectives and protocol of the study which was conducted in accordance with the ethical principles stated in the "Declaration of Helsinki" and approved by the University of Health Sciences, İzmir Tepecik Training and Research Hospital Ethics Committee (December 05, 2012; 42/14 approval number).

\section{RESULTS}

Behaviors That Contribute to Unintentional Injuries. The rate of person who not wear seat belt while travelling were in 499 (48\%). Similar rates were obtained from three different medcal schools: $46 \%$ in Ege University, $53.1 \%$ in Dokuz Eylül University, $42.6 \%$ in İzmir Katip Çelebi University. The rate of travelling with drunk driver in last 1 month at least 1 time were $130(12.5 \%)$ persons. The rate of drunk driving in last 1 month at least 1 time were $48(4.6 \%)$ persons.

Behaviors That Contribute to Intentional Injuries. The rate of carrying of a weapon in last 1 month at least 1 time were 52 ( 5\%) persons. Fifty five ( $5.3 \%$ ) persons were involved fighting physical in last 1 year at least 1 time. The rate of exposed sexual and phsycal violence in last 1 year were 58 ( $5.6 \%)$ persons. The planning to suicide in last 1 year were 30 ( $2.9 \%)$ persons.

Tobacco Use. Over the lifetime of those who had tried smoking at least once were 151 (14.5\%) persons. The ones smoking regularly were 137 (13.2\%). They were $3(2.1 \%)$ persons whom onset of smoking age were 10-13.

Alcohol and Other Drug Use. During his lifetime rate of at least one glass of alcohol drinkers, $388(37.3 \%)$ persons. Age of starting alcohol usage which was under 13 were 25 (6.4\%) persons. Using drug (other than smoke, alcohol) at least once in lifetime was $151(14.5 \%)$.

Sexual Behaviors That Contribute to Unintended Pregnancy and STDs, Including HIV. Among adolescents participating the study who had at least one sexual relationship in his or her life were165 ( $15.9 \%$ ) persons. Using birth control method in last sexual intercourse were $147(14.1 \%)$ persons; $74.5 \%$ using condom, $6 \%$ using oral contraception. Using alcohol or drug during last sexual intercourse were 58 $(35.3 \%)$ persons. $532(51.2 \%)$ persons got HIV education in their school.

Dietary Behaviors. It was asked to the students that how they percieve their weight; owerweight answer rates were $235(22.6 \%)$. Giving normal weight answers were $617(59.3 \%)$. Giving underweight answer were $148(14.2 \%)$. For weight loss or in order to protect those weight by making diet in last 30 days were 196 $(18.8 \%)$ persons. Those who made exercise in last 30 days for weight loss were $368(35.4 \%)$ persons. Eating vegetable or fruits > 1-2 service/day were $389(37.4 \%)$ persons.

Physical Activity._Watching TV more than 2 hours/day at school time $(33.1 \%)$ for girls, $(26.8 \%)$ for boys. Who have computer at home were $88.5 \%$. In last 7 days using computer regularly all day $65.2 \%$. 
The comparison of the survey evidence with 'Youth Risk Behaviour Surveillance' between USA and Turkey. The comparison of the survey evidence with 'Youth Risk Behaviour Surveillance' which made in USA in 1999, summaried at chart, there were significant statistical differences with these subjects; do not wear seat belt while travelling, travelling with drunk driver in last 1 month at least 1 time, carrying of weapon in last 1 month at least 1 time ,fighting physical in last 1 year at least 1 time,exposed sexual and physical violence in last 1 year, planning to suicide in last 1 year, smoking at least 1 time all life long, starting to smoke under 13 years old, drinking alcohol at least 1 time all life long, starting to drink alcohol under 13 years old, other drug use atleast once, having sexual act at least 1 time all life long, using condom at last sexual act, using oral contraceptive at last sexual act, drinking alcohol or taking medicine before the last sexual act, studying AIDS at school, feeding fruit or vegetable in last 7 days more than 1-2 serving/days, watching TV less than 2 hours/days at school time, using computer every day. There were not any significant statistical difference with the other evidences.

Table-1: The comparison of the survey evidence with the 'Youth Risk Behaviour Surveillance' between USA and Turkey

\begin{tabular}{|c|c|c|}
\hline & $\begin{array}{c}\text { USA (1999) } \\
(15349 \text { persons }) \\
\end{array}$ & $\begin{array}{r}\text { Turkey }(2013) \\
(1040 \text { persons }) \\
\end{array}$ \\
\hline \multicolumn{3}{|l|}{$\begin{array}{l}\text { Behaviors That Contribute to Unintentional } \\
\text { Injuries }\end{array}$} \\
\hline \multirow{3}{*}{$\begin{array}{l}\text { People who not wear seat belt while travelling } \\
\text { Travelling with drunk driver in last } 1 \text { month at } \\
\text { least } 1 \text { time } \\
\text { Drunk driving in last } 1 \text { month at least } 1 \text { time }\end{array}$} & $16.40 \%$ & $48 \%$ \\
\hline & $33.10 \%$ & $12.5 \%$ \\
\hline & $13.10 \%$ & $4.6 \%$ \\
\hline \multicolumn{3}{|l|}{$\begin{array}{l}\text { Behaviors That Contribute to Intentional } \\
\text { Injuries }\end{array}$} \\
\hline \multirow{4}{*}{$\begin{array}{l}\text { Carrying of a weapon in last } 1 \text { month at least } 1 \\
\text { time } \\
\text { Fighting physical in last } 1 \text { year at least } 1 \text { time } \\
\text { Exposed sexual and phsycal violence in last } 1 \\
\text { year } \\
\text { Planning to suicide in last } 1 \text { year }\end{array}$} & $17.30 \%$ & $5 \%$ \\
\hline & $35.70 \%$ & $5.3 \%$ \\
\hline & $8.80 \%$ & $5.6 \%$ \\
\hline & $19.30 \%$ & $10.5 \%$ \\
\hline \multicolumn{3}{|l|}{ Tobacco Use } \\
\hline \multirow{3}{*}{$\begin{array}{l}\text { Smoking at least } 1 \text { time all life long } \\
\text { Smoking among in last } 1 \text { month more than } 20 \\
\text { days. } \\
\text { Starting to smoke under } 13 \text { years old }\end{array}$} & $70.40 \%$ & $14.5 \%$ \\
\hline & $16.80 \%$ & $13.2 \%$ \\
\hline & $27.40 \%$ & $2.1 \%$ \\
\hline \multicolumn{3}{|l|}{ Alcohol Use } \\
\hline \multirow{2}{*}{$\begin{array}{l}\text { Drinking alcohol at least } 1 \text { time all life long } \\
\text { Starting to drink alcohol under } 13 \text { years old } \\
\text { Other drug use at least once }\end{array}$} & $81.00 \%$ & $28.3 \%$ \\
\hline & $\begin{array}{l}32.20 \% \\
26.7 \%\end{array}$ & $\begin{array}{l}6.4 \% \\
14.5 \%\end{array}$ \\
\hline \multicolumn{3}{|l|}{$\begin{array}{l}\text { Sexual Behaviors That Contribute to } \\
\text { Unintended Pregnancy and STDs, Including } \\
\text { HIV }\end{array}$} \\
\hline \multirow{5}{*}{$\begin{array}{l}\text { Doing sexual act at least } 1 \text { time all life long } \\
\text { Using condom at last sexual act } \\
\text { Using oral contraceptive at last sexual act } \\
\text { Drinking alcohol or taking medicine before the } \\
\text { last sexual act } \\
\text { Studying AIDS at school }\end{array}$} & $49.90 \%$ & $15.9 \%$ \\
\hline & $58.00 \%$ & $74.5 \%$ \\
\hline & $16.20 \%$ & $6 \%$ \\
\hline & $24.80 \%$ & $35.3 \%$ \\
\hline & $90.60 \%$ & $51.2 \%$ \\
\hline \multicolumn{3}{|l|}{ Dietary Behaviors } \\
\hline \multirow{4}{*}{$\begin{array}{l}\text { Thinking oneself overweight } \\
\text { Feeding fruit or vegetable in last } 7 \text { days more } \\
\text { than } 5 \text { serving/day } \\
\text { Efforting to lose weight in last } 1 \text { month } \\
\text { Making exercise in last } 30 \text { days for weight loss }\end{array}$} & $30.00 \%$ & $22.6 \%$ \\
\hline & $23.90 \%$ & $37.4 \%$ \\
\hline & $42.7 \%$ & $18.8 \%$ \\
\hline & $58.4 \%$ & $35.4 \%$ \\
\hline \multicolumn{3}{|l|}{ Physical Activity } \\
\hline \multirow{2}{*}{$\begin{array}{l}\text { Watching TV more than } 2 \text { hours/day at school } \\
\text { time } \\
\text { Using computer every day }\end{array}$} & $57.20 \%$ & $33.1 \%$ (girls) $26.8 \%$ (boys) \\
\hline & & $65.2 \%$ \\
\hline
\end{tabular}




\section{DISCUSSION}

In developed countries (especially USA) owing to their impact on health care systems, addressing multiple risk behaviors has become an urgent health priority [13]. Although behavioral modification can decrease morbidity and mortality and increase quality of life [14], the opportunities to address youth health behaviors in strategic settings often are missed. In this respect, made a survey system by $\mathrm{CDC}$ and national surveys in 1990, 1991, 1993, 1995, 1997 and 1999 in USA [8]. Through this system, it became an important subject to protected against risky health behaviour at adolescent age. Reducing the morbidity and mortality in adolescent age, through the protected method, will get success in accidents which are the main factors [15]. The traffic accidents are the first within the accidents [6]. The risky behaviours to the contribution of traffic accidents (especially not to fasten seat belt in the car) was identified highly in workgroup. In USA, the death at adolescent age get decrease due to raising the legal age for using alcohol, making legal arrengement for driving alcoholic and obligation for using seat belt. In order to make similar reduction in our country, to ensure effective controls and detterant penalities to gain qualifications required.

Suicide is one of the frequent cause in adolescent and young death. In our work group the rate is less than USA. In literature, it is emphasized that the adolescent suicide is related to depression[15]. Because of this, it is necessary to make early diagnosis and therapy for depression at adolescent to reduce the suicide rate.

Smoking does not only increase the risk of devoloping diseases but also leads to environmental damages and brings burden on the country economy [15]. After the new legal regulation, cigarette companies start campaigns on the women and adolescents. Considering that who starts to smoke at adolescent age will smoke at age of adult, it is forced to be active to wage war against smoking at this age. It is known that drinking alcohol at adolescent age, increases the risk of addiction and entoxication [15]. Addiction of alcohol is one of the main factor to prepairing the ground of the accidents, suicides and murders. The rate of drinking alcohol in our workgroup is quite less than Youth Risk Behaviour Surveillance. Sexual activity may be risky in same cases [15]. Especially decreasing the age of the first sexual act is very important risk factor. In our workgroup the rate of sexual acts and using oral contaceptive is less than USA, however using condom is more. The large part of adolescent in our workgroup, indicated not to study about AIDS. For our country, sexual health policies and programmes covered especially adolescent and young adults is necessary. At adolescent age perceiving the body weight is frequent problem [17]. Especially among girls, increasing fat in body and expansion in hip, may perceiving as obesity by them [17]. The girls in puberty must enlighten for normal changes and provide to have realistic expectations for their physical growth. This may reduce the problems in this subject. Today most of the adolescents are fed by enriched fat and salty called fastfood and eat less amount of fruit and vegetable [9]. It is seen that almost half of the adolescents who join in our work ate no fruit in last seven days. It is necessery to take preventions to change the diet habits of the adolescents. Educational programmes must be taken covered in family life, pre-school and school period.

\section{CONCLUSION}

The leading causes of morbidity and mortality among youth and adults in the world are related to six categories of priority health-risk behaviors; behaviors that contribute to unintentional injuries and violence, tobacco use, alcohol and other drug use, sexual behaviors that contribute to unintended pregnancy and sexually transmitted diseases, unhealthy dietary behaviors and physical inactivity.

For the purpose of prevent the risky behaviours at adolescents, it is necessery to establish a counseling system to educate the teachers and health workers about the problems for this age. In our country there is no surveillance system as in USA and no certain datas for prior health risks. It will be useful to implement a same system.

\section{REFERENCES}

1. WHO. Adolescent Friendly Health Services, 2002. (accessed on: 09.08.2012) http://www.who.int/childadolescent-health/OVERVIEW/AHD/adh_over.htm

2. Tekgül N, Göktay GA, Dirik N, Karademirci E, Ongel K. Tepecik Education and Research Hospital, Family Medicine Clinic, Alsancak example of Adolescent Counseling and Health Service Center, ÇİDEM. Smyrna Tip Dergisi. 2012; 2(1-ek1):33-35.

3. Di Clemente R, Wingood GM, Crosby R. Parenteral monitoring: association with adolescents' risk behaviours. Pediatrics. 2001; 107: 1363-1368.

4. WHO 1999. Programming for Adolescent Health and Development, Report of a WHO/UNFPA/UNICEF Study Group on Programming for Adolescent Health, WHO Technical Report Series, No: 886, Geneva.

5. Youth risk behavior surveillance United States, 2003. [http://www.cdc.gov/mmwr/preview/mmwrhtml/ss5302a 1.htm ]

6. Tenore JL, Lipsky MS. Preventive services for the adolescents (13-20 years). Pediatr Clin North Am. 2001; 48: $289-311$.

7. U.S. Department of Health and Human Services. 2000. Healthy People 2010. 2nd ed.Washington, D.C.

8. Kann L, Kinchen SA, Williams BI. Youth Risk Behaviour Surveillance - United States, 1999. MMWR 2000; 49: 1-31.

9. Feldman E. Adolescent health: risks, resilience, prevention. Clin Fam Pract. 2000; 2: 767-790. 
10. Kolbe LJ, Kann L, Collins JL. Overview of the Youth Risk Behavior Surveillance System. Public Health Rep. 1993;108(suppl 1):2-10.

11. Karal B, Hatun S, Aydoğan M, Babaoğlu K, Gökalp AS. Kocaeli ilindeki lise öğrencilerinde sağlık açısından riskli davranışların değerlendirilmesi. Çocuk Sağlığı ve Hastalıkları Dergisi. 2003; 46:30-37.

12. Ercan $\mathrm{O}$, Alikaşifoğlu $\mathrm{M}$, Erginöz $\mathrm{E}$ ve ark. İstanbul lise gençlerinde riskli davranışların sıklığı ve cinsiyete göre dağılımı -Cerrahpapa Gençlik Sağlığı Araştırması- 2000. Türk Pediatri Arşivi. 2001; 36: 199-211.

13. Pronk NP, Peek CJ, Goldstein MG. Addressing Multiple Behavioral Risk Factors in Primary Care: A Synthesis of Current Knowledge and Stakeholder Dialogue Sessions. American Journal of Preventive Medicine. 2004;27:4-17.
14. Koop E. Health Promotion and Disease Prevention in Clinical Practice. In: Health Promotion and Disease Prevention in Clinical Practice. ed. RS Lawrence, SH Woolf, S Jonas, vii-ix. Baltimore:Williams andWilkins; 1996.

15. Health 21. The health for all policy framework for the WHO European Region. Copenhagen: European Health for All Series.1999; 6: 40-95.

16. Reeve A. Recognizing and treating anxiety and depression in adolescents. Med Clin North Am. 2000; 84: 891-904.

17. Joffe A. Why adolescent medicine? Med Clin North Am. 2000; 84: 769-785. 